\title{
The Analysis of Teaching Methods of University
}

\author{
Yanni Zhao \\ Qilu university of polytechnic, Department of Finance \\ Jinan City, Shandong Province, China, \\ snsnzyn@163.com
}

\begin{abstract}
In the current higher education reform, the innovation of teaching methods is essential and the task is very arduous. Teaching methods require changes in teaching philosophy to make the necessary reforms. International teaching philosophy, combined with the actual situation of higher education in our country is related in the educational scientific research under the guidance of the modern teaching philosophy.
\end{abstract}

\section{Keywords- college; teaching methods}

\section{INTRODUCTION}

With the corresponding teaching problems, there are six problems in the study of the students.(1) In the way of learning, students are lack of autonomy. Many students are dependent on the classroom. The initiative and the independent learning ability are not enough to study.(2) Way of thinking is much more same. With many years of teaching standards, students reading textbooks and understanding lectures are the same. Training is also seeking the same thinking rather than seeking the other thinking.(3)On the learning state, the students are excessive compliant. The problems are too little. Learning to think, asking questions, researching questions and solving problems are the most important way to move forward. Diligent students are willing to think and to ask questions, however, there are too small. Students in learning are not asking questions, which in itself is a big problem in learning.(4) Inheritance excessive, innovation too little. The inheritance in study is necessary. However, there should be more emphasis on innovation in university. Many students have not well learned of learning styles and the innovative learning is not enough.(5) Learning interesting is too little. Learning needs interest which can really mobilize student's inner motivation to study, and truly become the masters of their own learning. (6) In the learning standards, common too much, personality too little. Learning requirement of students tends to be uniform, so that students are trained to be the same, but lack of personality. To develop their own personality and optimize themselves, each student should pay attention to the problem.

The above problems also affect the status of student learning, learning levels and learning outcomes, restricting personnel training quality. School without learning is reflected by student's learning atmosphere and state, such as the students to preview, after-school refresher, practice these basic aspects, or not doing, or not doing enough. Lack of the process of digestion of learning, understanding and consolidate, it is difficult to turn the knowledge of others into their own knowledge. At the entrance to the Children's Museum in Washington, writing this sentence: "What I hear will forget, but what I see can be remembered, which I really understand." "Knowledge" means recognition, judgment, analysis, digestion and processing information. "Knowledge" is to accept other person's thinking, embodied the tradition; "knowledge" is a self-processing and operations, reflecting the innovative. Over the years our university classroom focuses on imparting knowledge, teaching mainly to the inheritance. We pay more attention to "know", but not "knowledge". It is not conducive to the cultivation of students' innovative spirit. Too much emphasis on the inculcation of knowledge in the classroom, the students will be back some provisions and knowledge, but the spiritual guide aptitude is not enough, not yet translated into good values and high moral quality. In order to solve such problems, it is necessary to reform the teaching method.

\section{II.LEARNING OF TEACHING METHODS FROM FOREIGN UNIVERSITIES}

Under the guidance of the concept of modern teaching, foreign universities have explored and reformed of teaching methods. Good teaching methods are widely recognized. The teaching methods include case method, problem-based learning and project-based learning.

\section{A. Problem-based learning}

In 1970, Problem-based learning is founded by Canada McMaste which is an university school of Medicine. Now, Problem-based learning is not only widely used in the Medical School and the Technical College, but also widely used in engineering education, training in project design and implementation face courses. The method is a problem-solving skill which focus on learning in a meaningful comparison of complex problem situations, designed to allow students to work together to solve the question of the authenticity, by learning to master the scientific knowledge implicit in the background to the issue. The aspects of problem-based learning includes organizational group, reflecting on five links in the start of a new, follow-up action to report the problem. From the actual questions by teachers in the teaching process, the implementation of problem-based learning is small group learning, where students are learning the subject. Students can have ways to relevant information to design and adjust 
learning programs, organization of seminars, the final form of a written report and an oral report to complete the learning task. In the process of writing complete conference organization, project report writing and preaching, the students exercise the organizational skills and ability to communicate. This method is needed to learn new knowledge, and to improve students' ability to learn in the process to acquire new knowledge.

\section{B. Case Method}

The Case Method was begun at Harvard Business School, where a teacher and student are directly involved in teaching methods. These cases comes from the actual work situations, through the guidance of teachers on the basis of discussion, students in their own reading, research, class discussion. Teaching has a unique source, nature, content scheduling system. Teaching methods do not only point teachers, but also require that teachers and students should have a significant change in behavior. Case teaching is carried out by the actual case study and discussion, and its focus is on the students' creativity, as well as the actual development of problem-solving skills. The case teaching allows students have access to knowledge, experience and activities, and through discussion and analysis of the case, to improve the ability to express. The case teaching greatly lessens the gap between teaching situations with real life situations. Students can put themselves into the actual situations, and imagine the difficulties that may be encountered, thereby enhancing the ability to design a variety of solutions to the problems.

It is shown that both problem-based learning and case teaching method are similar in the creation, reality similar teaching scenarios, fully stimulating and enhancing students' interest in learning and work adaptability. Analysis is the solution of the problem, because there is no standard answer. The answer based on the accumulation of knowledge and experience of everyone is personalized and creative. In both problem-based learning and case teaching method, teachers are no longer classroom manipulators, controllers, but a facilitator of learning, promote and mentor. Students from passive learners become active learners. This change leads to the migration of the status of teachers and students in the classroom from the traditional teacher-centered to student-centered migration. It reflects more interactive relationship of cooperation and exchanges between students and teachers. Teaching methods reflects the effectiveness of modern teaching philosophy that is embodied modern teaching reform to student-oriented and competence-based rational choice and value orientation.

III. TO PROMOTE INITIATIVES IN THE REFORM OF TEACHING METHODS

\section{A. Change the traditional concept of quality education}

As we all know, the quality of education has been stressed before high school, which only shows that the high school is lack of quality education, and it is very difficult to promote quality education in the university classroom. The key is to change the traditional concept of quality education. The bell rings just meaning a full stop, and we all think that is a good lesson. In fact, the bell ringing means that it leaves some time for students to think the lecturing process. For the students, the teaching model lacks the essential difference between university classroom and before high school. Although they came in high school, college classroom does not bring them fresh feeling. The authors do not think teaching abroad is advanced, but the enthusiasm of foreign teachers in teaching may be better than domestic. Therefore, the simple task of teachers in university in our country is different in essence. How to make college and middle school classroom to stimulate student interest in learning is a difficult matter.

\section{B. Change teaching assessment}

School teaching assessment by students has played a better role, but an unavoidable fact is that students give the scores higher and higher. Almost $90 \%$ of the teachers can get a score of 90 points or more. In fact, the students dissatisfies from time to time. The reason is that the original school teaching assessment is too much emphasis on the evaluation of the "teaching". Such as adequacy teaching preparation, the rich teaching content and clear expression, these should be the basic quality of teachers, students may not interested in. It is necessary to focus on the evaluation of the "learning", for example, whether there are interactions between students and teachers? Can students maintain interest in learning this course? Can you improve the ability of students to analyze and solve problems? And so on.

\section{To change teachers Score - pay much attention to the introduction of more elements in classroom}

There is much more to improve and learn teaching assessment. The number of students can actually get more than 90 points or even higher. The reason is the single final exam. The score is decided by two-hour exam, so it is unavoidable that there are some cheating behaves. Therefore, there is a need to introduce more elements of the learning process, to reduce the proportion of the final exam, to guide students to strengthen the learning process. Of course, due to the enrollment, many courses are taught in large class. How to strengthen the learning process is worth explored.

\section{REFERENCES}

[1] Yao liming, Break the Teaching Reform ice innovation university teaching methods, China higher education , vol.8,pp. 40-42, 2010.

[2] Ma fengqi, Wang weilian, Status of the reform of teaching methods in the reform of the personnel training mode, University Teaching in China, vol.3, pp. 11-13, 2009.

[3] Zhang dejiang, Reform of teaching methods to cultivate innovative talents, University Teaching in China, vol.5, pp. 7-10, 2009. 